\title{
Impact of Integrated Ethics Program on Nurses Knowledge and Performance at Rural Areas in Fayoum Region, Egypt
}

\author{
Safia Belal ${ }^{1,}$, , Hala Hassan Saied Khalil ${ }^{2}$, Fatma Mohamed Elnady ${ }^{3}$ \\ ${ }^{1}$ Medical Surgical Nursing, Faculty of Nursing, Ain Shams University, Cairo, Egypt \\ ${ }^{2}$ Community Health Nursing, Faculty of Nursing, El-Fayoum University, Fayoum, Egypt \\ ${ }^{3}$ Administration Health Nursing, Faculty of Nursing, El-Fayoum University, Fayoum, Egypt
}

Email address:

Sofy3131@gmail.com (S. Belal)

${ }^{*}$ Corresponding author

\section{To cite this article:}

Safia Belal, Hala Hassan Saied Khalil, Fatma Mohamed Elnady. Impact of Integrated Ethics Program on Nurses Knowledge and Performance at Rural Areas in Fayoum Region, Egypt. American Journal of Nursing Science.

Vol. 6, No. 3, 2017, pp. 240-250. doi: 10.11648/j.ajns.20170603.22

Received: April 4, 2017; Accepted: April 22, 2017; Published: April 27, 2017

\begin{abstract}
Ethical standards offer a context for behavior assessment, and nursing principles which influence nurses' goals, and approaches with patient care. The aim of this study to evaluate the Impact of Integrated ethics program on nurses practices in health centers at rural areas in Fayoum region, Egypt. A quasi-experimental design with pre and post-test was utilized. Convenience sample were used to collect 70 nurses from three maternal and child health centers in Fayoum region. Two tools were used to collect the data, First: Self-administered interview questionnaire. Second: A structured practice observational check list to assess nurses' practices. The main results, there was an improvement after the nursing intervention program in all aspects. Concerning nurses' knowledge there was $88.6 \%$ of them satisfactory pre- intervention while, post program they became $100.0 \%$ have satisfactory knowledge. The present study concluded that, implementation of the integrated ethics program had an efficient improving nurses' knowledge, and practice regarding integrated ethics in the rural areas, with highly statically significant differences in all the tested items between pre/post program implementation $(\mathrm{P}<0.001)$. The study recommended to establishment of in- service training programs, and continuous supervision in rural areas to raise nurses awareness regarding Integrated Ethics and motivate them.
\end{abstract}

Keywords: Integrated Ethics, Maternal and Child Health, Rural Nurse

\section{Introduction}

Ethics is concerned with 'right and wrong', although agreeing what is 'right' can be challenging. An understanding of ethics is essential to the delivery of skilled professional care. It is vital that nurses appreciate the value of ethics in their work. Code of Ethics is an attempt to define basic rules, or principles for determining what constitutes "good" or "right" behavior. As well ethics is relevant to clinical, practice-based issues and affects all areas of the professional nursing role $[16,6]$ mentioned ethics involves determining the best course of action in a certain situation. Ethical reasoning is the analysis of what is morally right and reasonable. Moreover ethics requires a critical analysis of actions or potential actions and helps the nurses to answer the questions for what should to do in this situation. Accordingly, ethics looks at how decide between right and offers away of examine, how live and how practice [38].

The concept of maternal and child health $(\mathrm{MCH})$ refers to promoted, preventive, curative, and rehabilitative health care for mothers and children. Also incorporates the health care aspects of obstetrics, pediatrics, family welfare, nutrition, children development and health education [30] mentioned that maternal-child health nurses often struggle with ethical and social dilemmas that affect families. The main objectives of $\mathrm{MCH}$ services are lifelong health, and the specific objectives are reduction of morbidity and mortality rate for mother and children. Promotion of reproductive health. and promotion of physical and psychological development of the child within family [21] and [12]. 
The healthcare facilities needs of individuals living in rural areas who are different than in urban. These differences are the result of geographic, demographic, socioeconomic, workplace, and personal health factors. For example, many rural communities have a large proportion of elderly people and children [17] and [30] People living in rural areas often suffer from a lack of access to healthcare. People living in rural areas also have poorer socioeconomic conditions, less education, higher rates of tobacco and alcohol use, as well higher mortality rates when compared to their urban counterparts. Rural communities are also high rates of poverty amongst rural dwellers in many parts of the world, and poverty is one of the biggest social determinants of health $[13,14]$.

Routine and personal health choices have an impact on the health and expected permanence of individuals in rural areas. People from rural areas report higher rates of smoking, exposure to second-hand smoke, and obesity than those in urban $[32,10]$

For this reason greater understanding about conflicts and misunderstanding that may arise from the differences among people could help rural nurses to find better solutions for ethical dilemmas and other common problems to daily life. Any approaches can be used to solve ethical dilemmas in nursing practice, but no single approach guarantees a right decision. The rural nurse must provide a logical, systematic method for decision making $[19,35]$.

Rural nurse must be aware of the confidential nature of information obtained in daily practice. Trusting relationship that establishes and maintains on upon atmosphere is one of the positive ideas for all health care providers to afford high quality of care [8]). However [9] add regardless of the amount of autonomy that the patients have in $\mathrm{MCH}$ care areas, the patients still depend on the rural nurse for many types of physical care and emotional support.

Furthermore, $[15,29]$ they reported that comparable of the other ethical principles, fidelity extends to the family of the $\mathrm{MCH}$ care patients, and when a promise is made to family members. They will be called if an emergency arises or they will be informed for any other special events concerning the patients. On behalf of that the rural nurse must make effort to follow the promises with the patients and their family. On other hand $[7,28]$ reinforced that the fidelity supports the rural nurse, family relationship and reflected positively on the nursing profession and on the institution.

Integrated ethics is a necessary elements for high quality of patient care and it is essential for well-being of the patient and the staff. Attention now a day directed towards improving the safety in the rural health care setting, not only to patients but also for health care providers and community members. To end with, the nurses has to respect freedom of choice for patient's justice and ethical principles as well personal information [19].

All practicing nurses and health care providers must acquire a certain number of continues education hours or attend expedient programs to help them for better practice with patients. Also provides an opportunity for nurses to explore new ways to eliminate gaps between nursing knowledge and patient care through effective performance. Integrated ethics program for nurses in rural areas consider a greatest achievement in gaining knowledge and educate them how to deal with patients and their families $[20,25]$.

\subsection{Magnitude of the Study}

Nurses play imperative roles in providing care throughout their daily interactions with patients in $\mathrm{MCH}$ [39]. The nurses are undoubtedly confronted with various ethical codes of conduct and the essentials of ethical decision making. Recognizing the ethical values can help to advance nursing practice and develop codes of ethics. As well recognizing ethical values in various communities can help nurses to understand the meaning of patients care with different cultures [25]. The reason of conducting this study is lacking of the study done in the Egypt about the integrated ethical among the health care providers. Therefore, this study is going to provide a unique identification on nurses' level of knowledge about the integrated ethics. As well it will improve nursing practice and improvement of patients safety. The upcoming impact of this study will reflect on the beneficial relationship and quality of care provided by nurses in $\mathrm{MCH}$.

\subsection{Aim of the Study}

To evaluate the effect of integrated ethics program on nurse's practices in $\mathrm{MCH}$ centers at rural area through:

a) Assessing the nurses' level of knowledge regarding Integrated Ethics at $\mathrm{MCH}$ centers.

b) Assessing the nurses' performance regarding Integrated Ethics at $\mathrm{MCH}$ centers.

c) Designing and implementing training program based on the assessment.

d) Evaluate the effect of intervention program on nurses' knowledge and performance regarding integrated Ethics at $\mathrm{MCH}$ centers.

\subsection{Research Hypotheses}

The integrated ethics program will improve the nurses' level of knowledge and practice regarding ethics in $\mathrm{MCH}$ centers.

\section{Subject and Methods}

\subsection{Design}

A quasi-experimental design with pre and post-test was used to accomplish the aim of the study.

\subsection{Setting}

The study was conducted at three maternal child health centers in 3 villages (Keman, Sanours, and Alsad El-aly) belong to Fayoum governorate, Egypt.

\subsection{Sample}

A none probability convenience sample of 70 nurses was 
collected and distributed as $\mathrm{MCH}$ at Keman villages(20 nurses), $\mathrm{MCH}$ at Sanours villages (35 nurses), $\mathrm{MCH}$ at Alsad El-aly villages (15 nurses).

Inclusion criteria

a) Male and female nurses.

b) Had more than two years of experiences in $\mathrm{MCH}$.

c) Ages was ranged between 20 to 40 years old.

d) With different educational levels (diploma nurses, technical nurses and Bachelor degree nurses).

Exclusion criteria

a) Nurses not willing to participate in the study.

b) Nurses less than two years experiences less in $\mathrm{MCH}$.

\subsection{Tools}

Two tools were utilized to gather the required information and consumed around four months.

\subsubsection{Tool (I): Structured Questionnaire}

Self-administered structure interviewing questionnaire was developed by the researchers based on reviewing recent and related literatures $[33,9,15]$. It was anonymous, written in English language and translated to Arabic language to fitting the sample criteria. It was reviewed by panel of expertise from Fayoum Nursing College and nursing supervisors from the selected $\mathrm{MCH}$, it was divided into two parts:

Part one: Socio demographic characteristic of nurses which includes information about age, sex, marital status, level of education, years of experience, sources of information, workshops, and site of work at center. It had a combination between open ended questions and closed question.

Part two: Which includes 47 questions about nurses' knowledge regarding professional ethical practices, it was close-ended questions.

Scoring system:

The questions contain items related nurses knowledge about concept of ethical practices, fundamentals and standers of professional ethical practices, and moral duties of nurses. The nurses' knowledge was calculated for each item as follows: complete and correct answer was scored 1 point, while don't know or wrong answer was scored zero point. The total score for all questions related to nurses' knowledge was collected as $<60 \%$ was considered satisfactory and $>$ $60 \%$ was considered unsatisfactory.

\subsubsection{Tool (II): Practice Observational Check List}

It was structure to assess nurses' practices: autonomy, justice, client rights, veracity, fidelity and fulfillment, double effect, beneficence, documentation, and confidentiality. It was adapted and modified from [28] It was written in English language.

Scoring system:

The nurses' practices through observational checklist were calculated for each item as follows; complete and correct practice was scored 2 points, incomplete correct practices was scored 1 point, the total score for all questions related to nurses' practices was collected as $<60 \%$ was considered satisfactory and $>60 \%$ was considered unsatisfactory.

\subsection{Tool Validity and Reliability}

Content validity of the study was tested by three expertise in the field of community health nursing; and two expertise from community department, Faculty of Nursing, Fayoum University, Egypt. The expertise reviewed the tools for clarity, relevance, comprehensiveness, simplicity and, modification for certain items was done. Testing reliability of the proposed tools was done statistically by Crombach $\alpha$ (alpha).

\subsection{Pilot Study}

Pilot study was carried out on $10 \%$ ( 7 nurses) after tool development, to evaluate the content of tools applicability and identify the estimated time for data collection. The pilot study was consuming about one month from the beginning to the end October 2015. Data gained from the pilot was analyzed and modification was done accordingly. As well the pilot were excluded from the study sample to avoid sample bias and contamination.

\subsection{Ethical Consideration}

The agreements for participation of the subjects were taken after the aim of the study was explained to them. Before data collection, the nurses were informed about the aim of the study and what would be done with the results. They were given the opportunity to refuse to participate and they could withdraw at any stage of the research. Also, they were assured that the information would remain confidential and used for the research purpose only. The researcher gave copies from the developed integrated ethics program material to nurses for achieving the ethical principles of research as well as the principle of beneficence. The ethics committee approval is in the College of Nursing, Fayoum University, Egypt on the subject of research.

\subsection{Procedure of Data Collection}

1) A reviewing of past and current literature covering the various aspects of the problem was done using books, articles periodicals, magazines and studies related to ethics in nursing.

2) Approval:

a) Official letters were issued from Faculty of Nursing, Fayoum University, Egypt, and sent to the director of $\mathrm{MCH}$ center to get their permission for data collection from the authorized personal.

b) The letters explained the purpose of the study, and sought their cooperation.

c) Data were collected during the first of September 2016 to the end of December 2016.

3) Before starting the data collection, the agreements and the aim of the study were explained to each head of nursing at $\mathrm{MCH}$ centers to gain their cooperation.

The nursing intervention program was constructed on four phases: 
1. Assessment phase:

a) In the first interview researchers introduced them self to each participant; a full explanation about the study was done.

b) The researchers collected the demographic data of the nurses, Nurse's knowledge and performance about integrated ethics. Then the intervention program was designed based on the results of assessment (pre-test and using the interviewing questionnaire and the observation checklists).

2. Planning (preparatory)Phase:

a) This phase based on outcomes obtained from the assessment phase.

b) The program content and media, posters, and visual materials) were prepared by the researchers for patients under the study based on patients' learning needs.

c) This program was supplemented using a diversity of teaching methods that included (lecture, discussion, clinical training, case study, and brain storming).

3. The implementation phase:

a) The program was implemented for the study group in the previously mentioned setting.

b) The researchers conduct the intervention program after finishing the pre-test in form of questionnaire and observational checklist.

c) The researchers were used different audiovisual aids such as; data show and pictures.

d) The researchers visited 3 different $\mathrm{MCH}$ centers in previously mentioned villages. The collection process starting from $9.00 \mathrm{am}$ to $2.00 \mathrm{p} . \mathrm{m}$. for 3 days' weekly, and it was conducted in the meeting room to fill in the questionnaire.

e) Each nurse took about 45 minutes to fill in the questionnaire; the researcher took nearby one hour to evaluated ethical practices for every nurse by eye observation.

f) At the beginning of each session, the researchers started by giving a summary about the previous session and explaining the objective of the new one.

g) The duration of each session ranged from 30-45 minutes, followed by 5-10 minutes for a summary and conversation of what has been accomplished.

h) The intervention program was covered the following topics (Professional ethics. The concepts of professional ethical practice in nursing. Knowledge related to fundamental rules of Professional ethics practice. Standers of professional ethical practice for nurses. Knowledge related to moral duties for nurses. Justice in treatment and communication. Patient's right. Trust and respect the patient's privacy.

i) The program composed of 8 separate main sessions (4 theories, and 4 practice sessions) for the nurses. Nurses were arranged into groups, each contained 23 nurses, according to the accessible time for them.

4. Evaluation phase:
Evaluation of the effectiveness of intervention program was done immediately after the intervention program using (post-test), through using the same pre-test tools. and three months later (follow up) through testing the nurses' knowledge, and practice related to integrated ethics with the patients in $\mathrm{MCH}$ in rural areas.

\subsection{Statistical Design}

Data were entered and analyzed using the Statistical Package for Social Sciences (SPSS) version 18.0. Demographic information was summarized using descriptive statistics in the form of frequencies and percentages. The calculated data was and tabulated using chi square for number and percentage distribution, and Paired $t$ test to examine the overall changes of the pre-test and post-test scores. One way Anova was used for mean and standard division. Independent $t$ test was also employed to compare the post-test score. Statistical significance was set at $p<$ 0.05. Statistical methods were applied (percentage, chi-square (X2), $\mathrm{P}$ value was considered that: non-significant (NS) if $\mathrm{P}>$ 0.05 , Significant (S) if $\mathrm{P}<0.05$, Highly Significant (HS) if $\mathrm{P}<$ 0.01 .

\section{Results}

The study came up with the following results:

Table 1. Distribution of the of nurses at MCH centers according to their socio- demographic characteristics $($ no $=70)$.

\begin{tabular}{lll}
\hline Characteristics & No & \% \\
\hline Sex & & \\
Male & 8 & 11.4 \\
Female & 62 & 88.6 \\
Marital status & & \\
Married & 60 & 85.7 \\
Single & 8 & 11.5 \\
Widow & 2 & 2.8 \\
Age in years & & \\
20-30 & 6 & 8.6 \\
30-40 & 38 & 54.3 \\
40+ & 26 & 37.1 \\
Educational level & & \\
Technical secondary schools & 64 & 91.4 \\
Technical health institute. & 2 & 2.8 \\
Bachelor & 4 & 5.8 \\
Years of experience & & \\
$<5$ & 10 & 14.3 \\
5+ & 8 & 11.4 \\
10+ & 52 & 74.3 \\
Mean=15.257+_ 7.38 range=3-25. & & \\
Previous attendance of integrated ethics training: & & \\
Training courses & 20 & 28.6 \\
Conferences & 50 & 30.4 \\
\hline
\end{tabular}

Table 1: It shows that the majority of nurses was female (88.8) and (85.7\%) were married as well only (11.43\%) of them were single. As regarding to level of education, the majority of them were graduates of technical secondary school of Nursing $(91.4 \%)$ and the rest of the studied nurses were either graduates of technical health institute (2.9\%). As concerning to previous attendance of integrated ethics 
training, only $28.6 \%$ of the nurses attended training courses, while $(30.4 \%)$ had attended conferences about Integrated
Ethics.

Table 2. Distribution of the nurses according to their Knowledge regarding integrated ethics pre/post program. ( $n=70)$.

\begin{tabular}{|c|c|c|c|c|c|c|}
\hline \multirow[t]{2}{*}{ Items } & \multicolumn{2}{|l|}{ Pre program } & \multicolumn{2}{|c|}{ Post program } & \multirow[b]{2}{*}{$\chi^{2}$} & \multirow[b]{2}{*}{ P-value } \\
\hline & $\begin{array}{l}\text { Satisfactory } \\
\text { knowledge } \\
\text { No/\% }\end{array}$ & $\begin{array}{l}\text { Unsatisfactory } \\
\text { Knowledge } \\
\text { No/\% }\end{array}$ & $\begin{array}{l}\text { Satisfactory } \\
\text { knowledge } \\
\text { No/\% }\end{array}$ & $\begin{array}{l}\text { Unsatisfactory } \\
\text { Knowledge } \\
\text { No/\% }\end{array}$ & & \\
\hline -Definition of integrated ethics & $\begin{array}{l}48 \\
68.6 \%\end{array}$ & $\begin{array}{l}22 \\
31.4 \%\end{array}$ & $\begin{array}{l}68 \\
97.1 \%\end{array}$ & $\begin{array}{l}2 \\
2.95\end{array}$ & 10.058 & $\begin{array}{l}0.0015^{*} \\
\text { (S) }\end{array}$ \\
\hline - Concepts of integrated ethical practices & $\begin{array}{l}24 \\
34.3 \%\end{array}$ & $\begin{array}{l}46 \\
65.7 \%\end{array}$ & $\begin{array}{l}62 \\
88.6 \%\end{array}$ & $\begin{array}{l}8 \\
11.4 \%\end{array}$ & 21.766 & $\begin{array}{l}<0.0001 * * \\
\text { (HS) }\end{array}$ \\
\hline - Moral duties as regard the integrated ethics & $\begin{array}{l}30 \\
42.9 \%\end{array}$ & $\begin{array}{l}40 \\
57.1 \%\end{array}$ & $\begin{array}{l}66 \\
94.3 \%\end{array}$ & $\begin{array}{l}4 \\
5.7 \%\end{array}$ & 21.477 & $\begin{array}{l}<0.0001 * * \\
\text { (HS) }\end{array}$ \\
\hline - Standards integrated ethical practices & $\begin{array}{l}30 \\
42.9 \%\end{array}$ & $\begin{array}{l}40 \\
57.1 \%\end{array}$ & $\begin{array}{l}58 \\
82.9 \%\end{array}$ & $\begin{array}{l}12 \\
17.1 \%\end{array}$ & 11.993 & $\begin{array}{l}0.0005 * \\
(\mathrm{~S})\end{array}$ \\
\hline $\begin{array}{l}\text {-Attitudes of nurses to protect the patient from } \\
\text { infection. }\end{array}$ & $\begin{array}{l}20 \\
28.6 \%\end{array}$ & $\begin{array}{l}50 \\
71.4 \%\end{array}$ & $\begin{array}{l}60 \\
85.7 \%\end{array}$ & $\begin{array}{l}10 \\
14.3 \%\end{array}$ & 23.333 & $\begin{array}{l}<0.0001 * * \\
(\mathrm{HS})\end{array}$ \\
\hline $\begin{array}{l}\text {-The fundamental rules of integrated ethical } \\
\text { practices for nursing }\end{array}$ & $\begin{array}{l}62 \\
88.6 \%\end{array}$ & $\begin{array}{l}8 \\
11.4 \%\end{array}$ & $\begin{array}{l}70 \\
100.0 \%\end{array}$ & $\begin{array}{l}0 \\
0.0 \%\end{array}$ & 4.242 & $\begin{array}{l}0.0394 * \\
(\mathrm{~S})\end{array}$ \\
\hline Steps of nursing care plane. & $\begin{array}{l}64 \\
91.4 \%\end{array}$ & $\begin{array}{l}6 \\
8.6 \%\end{array}$ & $\begin{array}{l}70 \\
100.0 \%\end{array}$ & $\begin{array}{l}0 \\
0.0 \%\end{array}$ & 3.134 & $\begin{array}{l}0.0767 \\
(\mathrm{NS})\end{array}$ \\
\hline -Important of consent and explanation. & $\begin{array}{l}68 \\
97.1 \%\end{array}$ & $\begin{array}{l}2 \\
2.9 \%\end{array}$ & $\begin{array}{l}70 \\
100.0 \%\end{array}$ & $\begin{array}{l}0 \\
0.0 \%\end{array}$ & 1.0145 & $\begin{array}{l}0.3138 \\
\text { (NS) }\end{array}$ \\
\hline -Maintaining the confidentiality of patient data & $\begin{array}{l}56 \\
80.0 \%\end{array}$ & $\begin{array}{l}14 \\
20.0 \%\end{array}$ & $\begin{array}{l}68 \\
97.1 \%\end{array}$ & $\begin{array}{l}2 \\
2.95\end{array}$ & 5.0806 & $\begin{array}{l}0.0242 * \\
(\mathrm{~S})\end{array}$ \\
\hline
\end{tabular}

(NS) not significant *(S) significant **(HS) highly significant

Table 2: Displays that $(97.1 \%)$ of the study sample had satisfactory knowledge regarding concept of professional ethics practices in health care setting post program comparing to $(31.4 \%)$ pre-program. The percentage of the studied nurses $(94.3 \%)$ had satisfactory knowledge regarding moral duties as regard the profession post program than (57.1\%) pre-program. As regarding to the consent and explanation the study indicated $(97.1 \%)$ of the nurses had satisfactory knowledge. While the small percentages of nurses $(2.95 \%)$ had unsatisfactory knowledge post program.

Table 3. Distribution of the nurses according to their total Knowledge score regarding the Integrated ethics program pre/post program at M.C.H centers $(n=70)$.

\begin{tabular}{|c|c|c|c|c|c|c|}
\hline \multirow{2}{*}{ Total nurses' Knowledge } & \multicolumn{2}{|c|}{ Pre program } & \multicolumn{2}{|c|}{ Post program } & \multirow[t]{2}{*}{$\chi^{2}$} & \multirow[t]{2}{*}{ P-value } \\
\hline & $\mathbf{N}$ & $\%$ & $\mathbf{N}$ & $\%$ & & \\
\hline Poor & 48 & 68.6 & 4 & 5.7 & \multirow{4}{*}{38.101} & \multirow{4}{*}{$\begin{array}{l}<0.0001 * * \\
(H S)\end{array}$} \\
\hline Average & 16 & 22.8 & 12 & 17.1 & & \\
\hline Good & 6 & 8.6 & 54 & 77.2 & & \\
\hline Total & 70 & 100.0 & 70 & 100.0 & & \\
\hline
\end{tabular}

$* *($ HS) highly significant

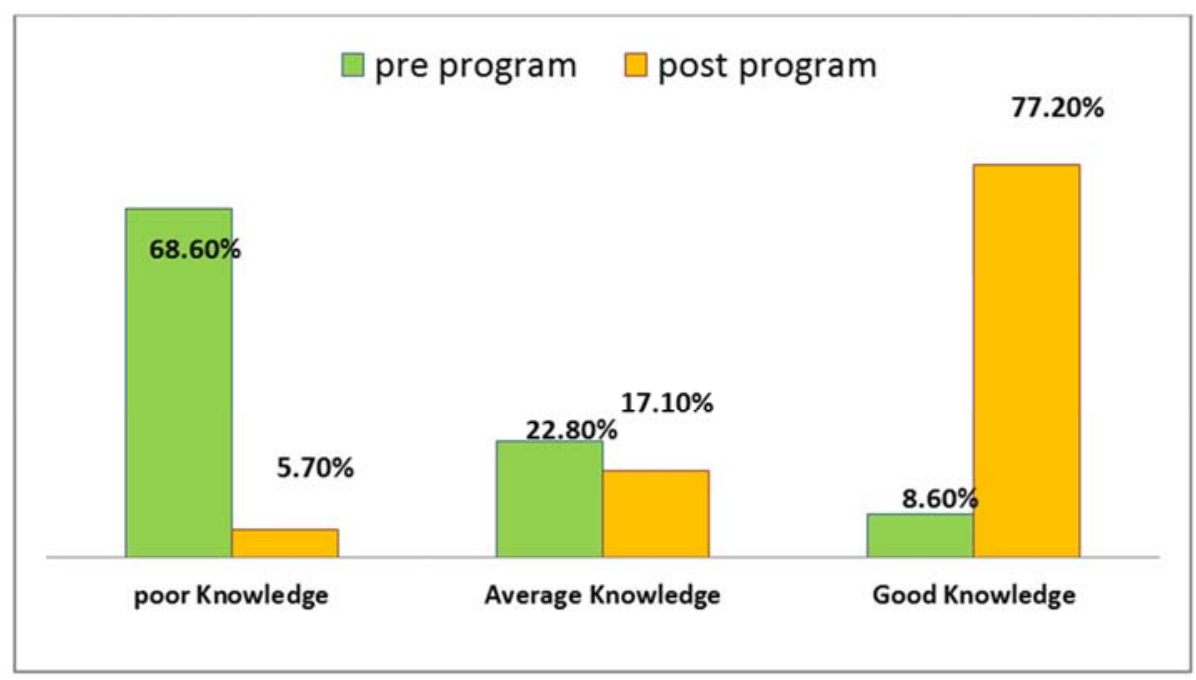

Fig. 1. Percent distribution of nurses Knowledge regarding to Integrated ethics pre/post program in M.C.H centers( $n=70)$. 
Table 4. Distribution of the nurses according to their performance regarding ethics after application of the Integrated ethics program pre/post program $(n=70)$.

\begin{tabular}{|c|c|c|c|c|c|c|}
\hline \multirow[b]{2}{*}{ Items } & \multicolumn{2}{|l|}{ Pre program } & \multicolumn{2}{|l|}{ Post program } & \multirow[b]{2}{*}{$\chi^{2}$} & \multirow[b]{2}{*}{ P-value } \\
\hline & $\begin{array}{l}\text { Satisfactory } \\
\text { performance } \\
\text { N/\% }\end{array}$ & $\begin{array}{l}\text { Unsatisfactory } \\
\text { performance } \\
\text { N/\% }\end{array}$ & $\begin{array}{l}\text { Satisfactory } \\
\text { performance } \\
\mathrm{N} / \% \\
\end{array}$ & $\begin{array}{l}\text { Unsatisfactory } \\
\text { performance } \\
\text { N/\% }\end{array}$ & & \\
\hline Respect during communication with others & $\begin{array}{l}26 \\
74.3 \%\end{array}$ & $\begin{array}{l}9 \\
25.7 \%\end{array}$ & $\begin{array}{l}33 \\
94.3 \%\end{array}$ & $\begin{array}{l}2 \\
5.7 \%\end{array}$ & 5.285 & $\begin{array}{l}0.0215^{*} \\
(\mathrm{~S})\end{array}$ \\
\hline Privacy during patient examination & $\begin{array}{l}10 \\
34.3 \%\end{array}$ & $\begin{array}{l}25 \\
65.7 \%\end{array}$ & $\begin{array}{l}31 \\
88.6 \%\end{array}$ & $\begin{array}{l}4 \\
11.4 \%\end{array}$ & 25.963 & $\begin{array}{l}<0.0001 * * \\
(\mathrm{HS})\end{array}$ \\
\hline respect of human being. & $\begin{array}{l}16 \\
45.7 \%\end{array}$ & $\begin{array}{l}19 \\
54.3 \%\end{array}$ & $\begin{array}{l}30 \\
85.7 \%\end{array}$ & $\begin{array}{l}5 \\
14.3 \%\end{array}$ & 12.428 & $\begin{array}{l}0.0004 * \\
(\mathrm{~S})\end{array}$ \\
\hline Gently treatment with the patient. & $\begin{array}{l}15 \\
42.9 \%\end{array}$ & $\begin{array}{l}20 \\
57.1 \%\end{array}$ & $\begin{array}{l}29 \\
82.95\end{array}$ & $\begin{array}{l}6 \\
17.15\end{array}$ & 11.993 & $\begin{array}{l}0.0005^{*} \\
(\mathrm{~S})\end{array}$ \\
\hline Explain purpose of therapy & $\begin{array}{l}10 \\
28.6 \%\end{array}$ & $\begin{array}{l}25 \\
71.4 \%\end{array}$ & $\begin{array}{l}32 \\
91.4 \%\end{array}$ & $\begin{array}{l}3 \\
8.6 \%\end{array}$ & 28.810 & $\begin{array}{l}<0.0001 * * \\
(\mathrm{HS})\end{array}$ \\
\hline - Respect freedom of choice for patient. & $\begin{array}{l}25 \\
88.6 \%\end{array}$ & $\begin{array}{l}10 \\
11.4 \%\end{array}$ & $\begin{array}{l}35 \\
100.0 \%\end{array}$ & $\begin{array}{l}0 \\
0.0 \%\end{array}$ & 11.667 & $\begin{array}{l}0.0006^{*} \\
\text { (S) }\end{array}$ \\
\hline Justice in arrangement of priorities. & $\begin{array}{l}27 \\
91.4 \%\end{array}$ & $\begin{array}{l}8 \\
8.6 \%\end{array}$ & $\begin{array}{l}35 \\
100.0 \%\end{array}$ & $\begin{array}{l}0 \\
0.0 \%\end{array}$ & 9.032 & $\begin{array}{l}0.0027 * \\
(\mathrm{~S})\end{array}$ \\
\hline Ask the patient separately. & $\begin{array}{l}29 \\
97.1 \%\end{array}$ & $\begin{array}{l}6 \\
2.9 \%\end{array}$ & $\begin{array}{l}33 \\
94.3 \%\end{array}$ & $\begin{array}{l}2 \\
5.7 \%\end{array}$ & 2.258 & $\begin{array}{l}0.1329 \\
(\mathrm{NS})\end{array}$ \\
\hline $\begin{array}{l}\text { Control disclosure of personal information and } \\
\text { limiting access of others to sensitive information. } \\
\text { Preservation of record and reports correctly and } \\
\text { Confidentiality }\end{array}$ & $\begin{array}{l}28 \\
80.0 \% \\
19 \\
54.3 \%\end{array}$ & $\begin{array}{l}7 \\
20.0 \% \\
16 \\
45.7 \%\end{array}$ & $\begin{array}{l}34 \\
97.1 \% \\
31 \\
88.6 \%\end{array}$ & $\begin{array}{l}1 \\
2.9 \% \\
4 \\
11.4 \%\end{array}$ & 10.08 & $\begin{array}{l}0.0242 * \\
(\mathrm{~S}) \\
0.0015 * \\
(\mathrm{~S})\end{array}$ \\
\hline
\end{tabular}

(NS) not significant $*(\mathrm{~S})$ significant $* *(\mathrm{HS})$ highly significant.

Table 4: Showed $74.3 \%$ of nurses reported that they respect others during communication, respect of human being was $45.7 \%$, and gently treatment with the patient $42.9 \%$, while $88.6 \%, 80.0 \%$ and $54.3 \%$ of nurses know respect freedom of choice for patient and control disclosure of personal information and preservation of record \& reports correctly and confidentiality pre ethical program intervention respectively, but after program they represented most and majority of them as, $94.3 \%, 85.7 \%, 82.9 \% .100 .0 \%, 97.1 \%$ \& $88.6 \%$ respectively with statistically significant differences. On other hand, regarding correct performance about privacy during patient examination and explain purpose of study pre intervention program $34.3 \%$ and $28.6 \%$, but after program, the majority and most of them was $88.6 \%$ and $91.4 \%$ correspondingly reported correct performance with highly statistically significant differences.

Table 5. Distribution of the nurses according to their performed adequate practices regarding principle of ethics and human right pre/post program. ( $n=70)$.

\begin{tabular}{|c|c|c|c|c|c|c|}
\hline & \multicolumn{2}{|c|}{ Pre program } & \multicolumn{2}{|c|}{ Post program } & \multicolumn{2}{|l|}{ Test } \\
\hline & $N$ & $\%$ & $N$ & $\%$ & $\chi^{2}$ & P-value \\
\hline \multicolumn{7}{|l|}{ Principle of ethics } \\
\hline Patient right to obtain of health care Information & 50 & 71.4 & 66 & 94.3 & & \\
\hline Listening to the patient with respect & 46 & 65.7 & 66 & 94.3 & & \\
\hline Provision of drugs and medical devices. & 46 & 65.7 & 70 & 100 & & \\
\hline Provide information for financial costs of treatment & 32 & 45.7 & 50 & 71.4 & & \\
\hline $\begin{array}{l}\text { patient's right to determine the names of medical staff } \\
\text { human right }\end{array}$ & 30 & 42.9 & 56 & 80 & 46.425 & $\begin{array}{l}0.003 * \\
(\mathrm{~S})\end{array}$ \\
\hline - patient's right to receive cleanliness and protection from diseases & 42 & 60 & 68 & 97.1 & & \\
\hline Tell the truth to the patient and not lie & 38 & 54.3 & 60 & 85.7 & & \\
\hline Prevention of violence against patient & 54 & 77.1 & 70 & 100 & & \\
\hline Informed the patient about his rights & 48 & 68.6 & 64 & 91.4 & & \\
\hline
\end{tabular}

Table 5: Demonstrates that $71.4 \%$ of nurses reported that patient right to obtain of health care Information, $65.7 \%$ of nurses reported that they listened to the patient with respect and provision of drugs and medical devices, $45.7 \%$ of them reported that they provide information for financial costs of treatment, $42 \%$ of nurses reported that patient's right to determine the names of medical staff, and $60.0 \%$ patient's right to receive cleanliness and protection from diseases, $54.3 \%$ of them they reported they provide information for financial costs of treatment, $77.1 \%$ of nurses reported that the principle of ethics was prevention of violence against patient, and 68.6 Informed the patient about his rights pre ethical program, but after program they represented most of them as, $94.3 \%, 100.0 \%, 71.4 \%, 80.0 \%$ and $97.1,85.7 \%, 100.0 \%$ and $91.4 \%$ after application of integrated ethical program with statistically significant difference. There is statically significant difference between total practices pre/post integrated ethical program $(\mathrm{x} 2=46.425 \mathrm{P}$-value $=0.003)$. 
Table 6. Distribution of the nurses according to their total performance score regarding ethics after the application of Integrated ethics pre/post program in M.C.H Centers $(n=70)$.

\begin{tabular}{lllllll}
\hline \multirow{2}{*}{ Total nurses' performance } & \multicolumn{2}{l}{ Pre program } & Post program & & \multicolumn{2}{c}{ P-value } \\
\cline { 2 - 5 } & $\mathbf{N}$ & $\mathbf{\%}$ & $\mathbf{N}$ & $\mathbf{\%}$ & & $<0.0001 * *$ \\
Poor & 58 & 68.6 & 6 & 5.7 & \\
Average & 10 & 22.8 & 8 & 17.1 & \\
Good & 2 & 8.6 & 56 & 77.2 & & $($ HS) \\
Total & 70 & 100.00 & 70 & 100.0 & & \\
\hline
\end{tabular}

**(HS) highly significant

Table 6: Show that distribution of the nurses according to their total performance. Pre-program $68.6 \%$ of nurses had poor performance, $22.8 \%$ had average performance, and 8.6 of them had good performance, while post program $5.7 \%$ of them had poor performance, 17.1 of them had average performance and 77.2 of them had good performance respectively with highly statistically significant differences. There is a statistically significant difference between total performance pre/post integrated ethics program $(\mathrm{x} 2=46.374$, P-value $<0.0001 * *$ integrated ethics pre/post training program in M.C.H centers $(\mathrm{n}=70)$.

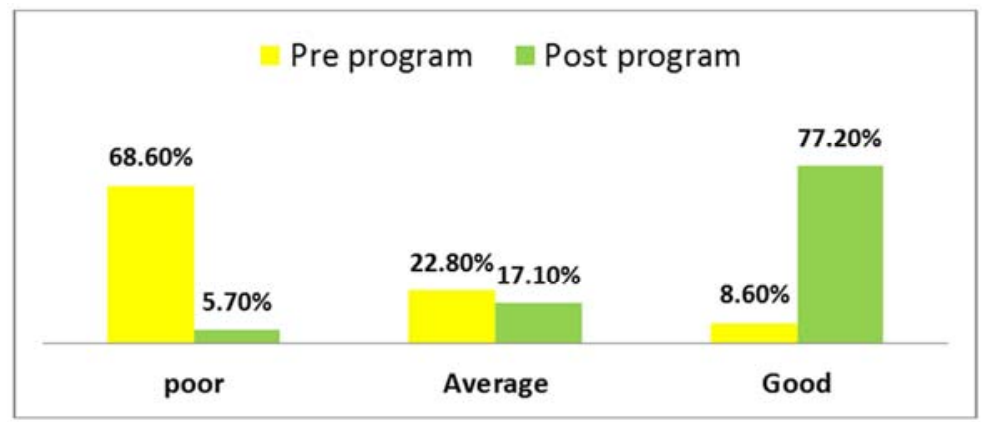

Fig. 2. Percent distribution of nurses performance regarding the integrated ethics pre/post program in M.C.H centers ( $n=70)$.

Table 7. Correlations between nurses performance and their knowledge about ethics after application of the integrated ethics program in MCH Center( $n=70)$.

\begin{tabular}{|c|c|c|c|c|c|c|c|c|}
\hline \multirow{3}{*}{ Total nurses' Knowledge } & \multicolumn{8}{|c|}{ Total nurses' Performance } \\
\hline & \multicolumn{2}{|c|}{ Poor } & \multicolumn{2}{|c|}{ Average } & \multicolumn{2}{|c|}{ Good } & \multicolumn{2}{|c|}{ Total } \\
\hline & $\mathbf{N}$ & $\%$ & $\mathbf{N}$ & $\%$ & $\mathbf{N}$ & $\%$ & $\mathbf{N}$ & $\%$ \\
\hline Poor & 46 & 65.7 & 2 & 2.8 & 0 & 0.0 & 48 & 68.5 \\
\hline Average & 12 & 17.1 & 4 & 5.8 & 0 & 0.0 & 16 & 22.9 \\
\hline Good & 0 & 0.0 & 4 & 5.8 & 2 & 2.8 & 6 & 8.6 \\
\hline Total & 58 & 82.8 & 5 & 14.4 & 2 & 2.8 & 70 & 100.0 \\
\hline \multirow{2}{*}{ Chi-square } & \multirow{2}{*}{\multicolumn{2}{|c|}{$\begin{array}{l}\mathrm{X} 2 \\
\text { P-value }\end{array}$}} & \multirow{2}{*}{\multicolumn{2}{|c|}{$\begin{array}{l}21.8247 \\
0.0002 *(\mathrm{~S})\end{array}$}} & & & & \\
\hline & & & & & & & & \\
\hline
\end{tabular}

*(S) significant

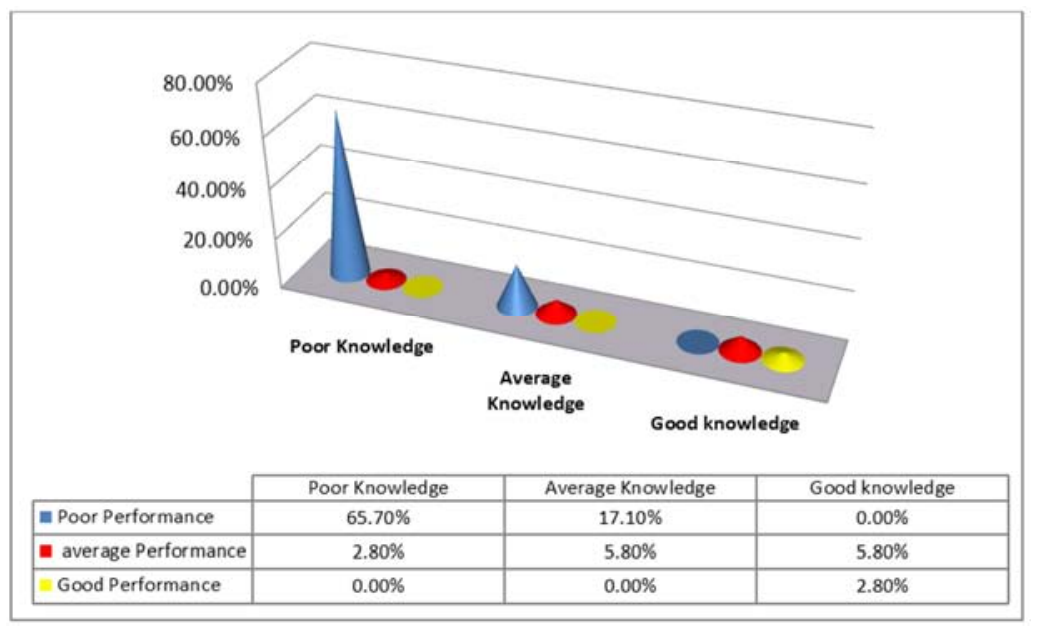

Fig. 3. Percent distribution for the correlations between nurses performance and their knowledge about ethics after application of the integrated ethics program in $\mathrm{MCH}$ Center $(n=70)$. 
Table 7 and Fig. 3: Indicates there was a highly statistically significant correlation between the nurses' total performance regarding integrated ethics and their nurses' knowledge pre/post after application of the integrated ethics program where $\mathrm{x}^{2}=$ $26.6875 \mathrm{P}<0.0001 * *$.

Table 8. Correlations between nurses total knowledge about integrated ethics and their Educational level in MCH centers ( $n=70)$.

\begin{tabular}{|c|c|c|c|c|c|c|c|c|}
\hline \multirow{3}{*}{ Nurses' Educational level } & \multicolumn{8}{|c|}{ Total nurses' knowledge } \\
\hline & \multicolumn{2}{|l|}{ Poor } & \multicolumn{2}{|c|}{ Average } & \multicolumn{2}{|c|}{ Good } & \multicolumn{2}{|c|}{ Total } \\
\hline & $\mathbf{N}$ & $\%$ & $\mathbf{N}$ & $\%$ & $\mathbf{N}$ & $\%$ & $\mathbf{N}$ & $\%$ \\
\hline Technical secondary schools & 48 & 68.6 & 16 & 22.9 & 0 & 0.0 & 64 & 91.4 \\
\hline Technical health institute. & 0 & 0.0 & 0 & 0.0 & 2 & 2.8 & 2 & 2.8 \\
\hline Bachelor & 0 & 0.0 & 0 & 0.0 & 4 & 5.8 & 4 & 5.8 \\
\hline Total & 48 & 68.6 & 16 & 22.8 & 6 & 8.6 & 70 & 100.0 \\
\hline Chi-sauare & \multicolumn{2}{|l|}{$X 2$} & \multicolumn{2}{|c|}{35.000} & & & & \\
\hline
\end{tabular}

**(HS) highly significant

Table 9. Correlations between nurses total performance about integrated ethics and their years of experience in MCH center ( $n=70)$.

\begin{tabular}{|c|c|c|c|c|c|c|c|c|}
\hline \multirow{3}{*}{ Nurses' Educational level } & \multicolumn{8}{|c|}{ Total nurses' Performance } \\
\hline & \multicolumn{2}{|l|}{ Poor } & \multicolumn{2}{|c|}{ Average } & \multicolumn{2}{|c|}{ Good } & \multicolumn{2}{|c|}{ Total } \\
\hline & $\mathbf{N}$ & $\%$ & $\mathbf{N}$ & $\%$ & $\mathbf{N}$ & $\%$ & $\mathbf{N}$ & $\%$ \\
\hline$<5$ & 10 & 14.3 & 0 & 0.0 & 0 & 0.0 & 10 & 14.3 \\
\hline $5+$ & 6 & 8.6 & 2 & 2.8 & 0 & 0.0 & 8 & 11.4 \\
\hline $10+$ & 42 & 60.0 & 8 & 11.4 & 2 & 2.8 & 52 & 74.3 \\
\hline Total & 58 & 82.9 & 10 & 14.3 & 2 & 2.8 & 70 & 100.0 \\
\hline Chi-sauare & $X 2$ & & 1.6 & & & & & \\
\hline
\end{tabular}

Table 10. Correlations between nurses total knowledge about integrated ethics and their years of experience in MCH center ( $n=70)$.

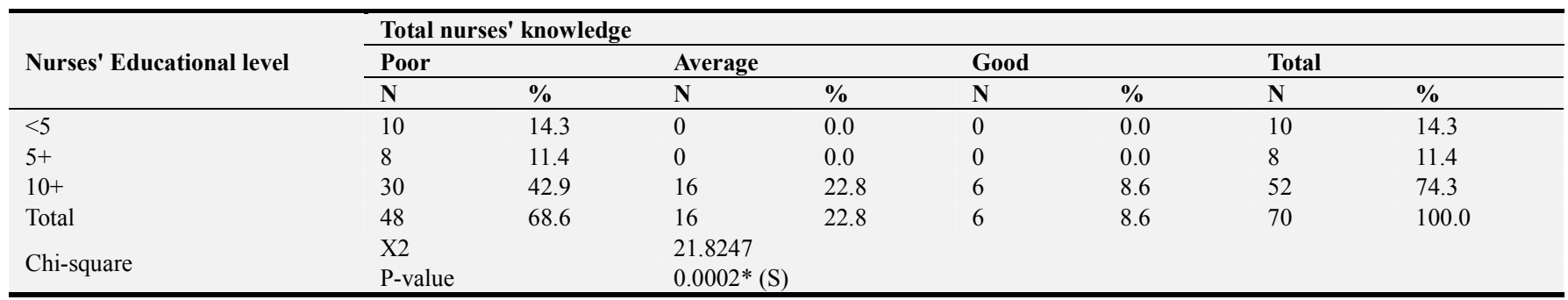

* (S) Significant

\section{Discussion}

Professional nurses must be prepared to face any number of potential ethical conflicts in the day to day practice of their profession. They must realize that each situation is different and that recognizing this uniqueness demands that responsible parties seek a loving and humane solution to every situation that poses on ethical dilemma. The decision maker must choose the most appropriate action, given the situation, based on a variety of potentially applicable principles [36, 34].

The findings of program intervention that was confirming the study hypotheses and executed that there was significant improvement of knowledge and performance regarding integrated ethics, these results are in line with [1] who stressed that suggested training program is effective in improving nurses' knowledge and performance regarding integrated ethics.

Regarding distribution of nurses in $\mathrm{MCH}$ regarding their socio-demographic characteristics:
Rregarding sociodemographic characteristics, the current studied showed that the majority of nurses under the study was females, and regard to the level of education, the majority were graduates of technical secondary school of nursing (91.4\%) However the vast minority represented technical institute in line with [2] who conducted a study to assess the awareness and knowledge of standard precautions among nurses in a university teaching hospital in Ajman, united Arab Emirates.

The present study elaborated that, petty number of nurses had attended training conferences in each of different nursing practice (Table 1). This study consisting with [23] who assess professional ethics practiced by nurses working in primary health Care centers in Port Said governorate, Egypt" who asserted that, some of nurses had attended training courses in each of different nursing practice. This result could be due to lack or shortage of nurses.

Regarding distribution of the nurses' Knowledge regarding integrated ethics pre/post program:

Concerning the nurses knowledge the current study findings showed that the findings of program intervention 
that was performed in this study revealed significant improvement in nurses' knowledge and performance regarding integrated ethics Table 2 and 3 . Those results were in the same line with other authors [1] who stressed that suggested training program is effective in improving nurses' knowledge and performance regarding integrated ethics. As well this result are consistence with [24] who conducted a study in western Algeria and observed that increase adherence to integrated ethics was primary due to increases of knowledge.

The findings of the present study revealed a significant improvement for nurse's knowledge related to definition of integrated ethics program, concept of privacy and confidentiality of information, moral duties regard the integrated ethics, As well those results reflected the weaknesses level of nurses 'knowledge before the program which in turn affects adversely on performance of integrated ethics (Table 2 and Figure 1).

In the same line with [21] in Britanie; who "assessed Knowledge, attitudes and practice of healthcare ethics and law among doctors and nurses in Barbados". The researcher illustrated that only $34 \%$ of nurses did not had knowledge regarding ethics. Also this study consisting with $[12,40]$ they revealed that, it is essential for nurses to understand and incorporate basic concepts of ethics into their practice.

Furthermore [3] reported a high degree of confusion and a lack of knowledge regarding standard precautions was observed among postgraduate nurses in Spain, However, the present study showed no significant improvements regarding nurses' knowledge about the elements that don't require application of integrated ethics and the concept of privacy and confidentiality of information this result for most nursing staff (Table 3). As well ethics in health care setting have emerged as important public health problem worldwide and are leading cause of morbidity and mortality in developed and developing countries [37, 4]. This result consisting with [31] in Iran who assessed "Nurses awareness of patients' rights in a teaching Hospital". They reported that $95.51 \%$ of nurses had good knowledge to preserve privacy and confidentiality of all medical information.

Concerning distribution of the nurses according to their performance regarding ethics after the application of the Integrated ethics (pre/post)program:

Nurses performance it was focuses on respecting nurses during communication with patients, privacy during patient examination, respect of human being, gently treatment with patient, and explain purpose of therapy. The present study revealed that nurses performance post program were significant between pre and post program (Table 4 and Figure 2). This result came in agreement with [13] who asserted that, the majority of nurses had good practices regarding preserving the patient's secrets and privacy. On the other hand, this result incongruent with [34] who conduct study about "New Zealand nursing students' experience of ethical issues in clinical practices". The researcher elaborated that more than two thirds of participants had experienced breach of patients' confidentiality and privacy, This result could be due to majority of studied nurses respect culture of rural areas and families' customs.

Concerning the carefully explanation for principles of ethics and human right, the nurses had a significant improvement between pre/post program (Table 5). This study is in agreement with [29] who reported that $60.7 \%$ of the studied nurses had explained procedures for patient. This result could be due to the effective following of the supervisors which force nurses to please by giving health education among patients. Moreover, the work at $\mathrm{MCH}$ such a critical place cannot bear any mistakes could make the life of the mother or her child endangered especially in case of RH- disease.

The current study is figuring out that majority of the studied nurses reported the deficiency of $\mathrm{MCH}$ center financial resources and the deficiency of allowance and supplies for providing the required standard of care. This result come in agreement with [27, 40] they stated that the main obstacle was financial and administrative factors. Majority of the studied nurses reported deficiency of M.C.H. center financial resources and the deficiency of allowance and supplies for providing the integrated ethics policy. The second author reported that the obstacle was lack of the nurses' knowledge and absence of good supervision which was reported by most of the studied nurses'. Work over load was reported by the majority of the studied nurses as they reported that the decrease in the number of nurses in M.C.H. center, the increase in number of the patients which affect negatively on the application of integrated ethics in M.C.H. centers.

Concerning to correlations between nurses performance and their knowledge about ethics after application of the integrated ethics program in MCH Center:

Regarding the correlation between nurses performance and their knowledge about integrated ethics in $\mathrm{MCH}$ centers, it was found that there was significant correlation between nurses knowledge about integrated ethics and their performance (Table 7 and Figure 3). This result come in agreement with $[29,18]$ they reported that increase in knowledge level lead to increase in the quality of performance and practice. Another study conducted by [28] about professional ethical practices by nurses working in maternal and child health centers, he found that there was significant relationship between nurses' knowledge about integrated ethics and their performance, this means increase in level of knowledge and in the quality of performance and practice.

According to barriers for performing integrated ethics procedures as stated by nurses during data collection, that, the only barriers to perform listening to patient with respect and patient right to obtain of health information are the lack of shortage in nurses. However As regards to other items of integrated ethics. It was a clear that the most frequent barrier to follow integrated ethics performances that the nurses were not used to perform these procedures accurately. This agree with [40] who mentioned that lack of resources and training opportunities, and excessive workload were the most 
frequent factors cited by health workers for not implementing integrated ethics during tasks.

Concerning correlations between nurses total knowledge about integrated ethics and their years of experience in $\mathrm{MCH}$ center:

In this studied the correlations between nurses total knowledge about integrated ethics and their years of experience in $\mathrm{MCH}$ center found significant improvement between them (Table 10). This result comes in agreement with [23] who had stressed that nursing problems in Egypt was classified into three big problems. Finally, the present study revealed that most of the studied nurses had good knowledge score but only half of them their performance of integrated ethics were good. This is considered a serious problem as they are exposed to various hitches and overload during their work, and directs. Which will be impacted toward nurses' role and toward improving nurses' knowledge and performance about integrated ethics. There was improvement in the nurses level of knowledge and practice post program implementation.

\section{Conclusion}

The present study exposed that most of the nurses had acceptable knowledge score, but only half of them their integrated ethics performance were good. This is considered a serious problem as they are exposed to various sources of disease during their work in M.C.H centers which considered as high risk for infection to all nurses, and their families as well to the surrounding community. Add on that, the study has a good impact on the nurses because it improved their knowledge about integrated ethical in the clinical setting.

\section{Recommendation}

There is a need to deliver regular training courses to rural nurses about ethical practices to give safe and proper legal and ethical care. As well provide training courses about effective communication to improve the level of dialogue with the patients in $\mathrm{MCH}$. Encouraging nurses to up-date their information regularly. The ministry of health should encourage Secondary Nursing School graduates' to complete their study and get Bachelor in nursing to provide high quality of patient care. Further studies are recommended to include other nursing specialities and students in a higher level to rise the power of generalizability of the findings. Pay more attention to the nurses in rural areas. Further research is required to assess the long-term effects of such program.

\section{References}

[1] Alexander, A., Wabster, K. (2010): Legal issues of infusion nursing, an evidence based approach, Louis, Mo: Souder's Elsevier, USA.

[2] American Nurses Association (ANA), (2015): Code of Ethics for Nurses. Retrieved November, 20, 2012 Avilable at: http://www.nursing world.org/code of ethics.

[3] Beauchamp, L. \& Childress, F. (2014): Principles of biomedical ethics $\left(6^{\text {th }}\right.$ ed.). Newyork, NY: Oxford university press.

[4] Beauchamp. L. \& Childress,. F. (2015): Principles of biomedical ethics $\left(7^{\text {th }}\right.$ ed.). Newyork, NY: Oxford university press.

[5] Bollig, G., Gjengedal, E., and Rosland S. (2016) Nothing to complain about? Residents' and relatives' views on a "good life" and ethical challenges in nursing homes, Nurse Ethics; 23(2): 142-153. Avilable at: https:/www.ncbi.nlm.nih.gov/pmc/articles/PMC4786778/

[6] Bosek, M. \& Savage, T. (2006): The ethical component for nursing education, Lippincott William \& Wilkins, USA.

[7] Brenda, G., \& Suzannc, C., (2010): Brunner \& Suddarths Textbook of Medical Surgical Nursing. $12^{\text {th }}$ ed., library of congress, China.

[8] Burkhardt, M \& Nathaniel, A, (2013): Ethics issues in contemporary Nursing, (4 ${ }^{\text {th }}$ ed)., U.S.A, ISBN, http://books.google.com.eg//books

[9] Canadian Nursing Association (CAN), (2015): Code of Ethics for Registered Nurses, Ottawa: ISBN 978-1-55119-282-9.

[10] Clark, P., (2010): A model for ethical decision making in cases of patient futility: Clin Nurse Spec,24(4):189.

[11] Cllister, L., \& Sudia Robinson, T.(2011): An overview of ethics in maternal-child nursing, Nursing, MCN: American Journal of Mternal and Child nursing, 36(3), 154-159

[12] Duffy, M., (2011): Nurse patient privacy and company policy in online life. American Journal of Nursing. 111(9).65-69.

[13] Ellis, p., (2014): Understanding ethics for nursing student, Christ Church University, USA.

[14] Epstein, EG. T, \& Delgado, S. (2010): Understanding and addressing moral distress. OJ J Nonline Journal of Issues in Nursing, 15(3). DOI: 10.3912/OJIN. VO15 Noo3 Man01.

[15] Fant, C. (2010): Ethical Dilemmas in Nursing. Nurse Together. Retrieved November 20, 2012 from: http://www.nursetogether.com/ career/career/career-Article/ itemed / 2520.aspx.

[16] Fowler, M., (2010): Guide to the code of Ethics for Nursing Interpretation and Application. Silver spring MD: American Nurses Association.

[17] Gastman, C. (2016): The care perspective in health care ethics. In A., J Davise, V. Tschuding, L. de Reave (Eds), Essentials of teaching and learning in nursing ethics (pp, 135148). London, England: living stone.

[18] Gosnell, K, \&Cooper, K,. (2015): Foundations and adult health Nursing, $\left(7^{\text {th }}\right.$ ed), Elsevier/Mosby. Canada, ISBN978-0323-10001-4

[19] Hamrin E, Potdar N, Anand R. Ethical values in health care: An Indian-Swedish co-operation. Nurs Ethics. 2002;9:439-47. [PubMed]

[20] Hariharanet et. al (2006): Ethics Education in Advanced Practice Nursing: Respect for human dignity, Nursing education perspectives, 28(4).196. 
[21] Han, S., \& Ahn, S., (2000): An analysis and evaluation of student nurses' participation in ethical decision making. Nursing Ethics, 7(2).113-123.

[22] Hassan, M., (2015): Assessment of professional ethics practiced by nurses working in primary health care centers in Port Said. Journal of American science 2012; 8(12). http://www.jofamericanscience.org.

[23] Helmy. F, \& Soliman, S., (2014): student's knowledge, student's attitudes, nursing ethics, patient's right issues: The New Egyptian Journal of Medicine 29(6).

[24] Horton K, Tschudin V, Forget A. The value of nursing: A literature review. Nurs Ethics. 2007;14:716-40. [PubMed].

[25] Hudoson, A., \& Melanie, (2013): Professional issues in speech- language pathology and audiology, $\left(4^{\text {th }}\right.$ ed.), Delmar Cengage learning, USA.

[26] Huerta, C, \& Maville, J, (2013): Health promotion in nursing, (3th ed.), Delmar Cengage Learning. USA, ISBN13-978-1111-64046-0.

[27] Ibrahim, W. (2015): Professional ethical practices by nurses working in maternal and child health centers, faculty of nursing Alexandria University.

[28] Mohammed, N., (2014): professional ethical practices versus client perception in community health centers. Faculty of Nursing Ain Shams University, (112).

[29] Murray, H. \& Mckinney, E. (2014): Foundations of maternal newborn and women's Health Nursing $\left(6^{\text {th }}\right.$ ed). U.S.A, ISBN: 978-1-4557-3306-4.

[30] Nejad et al. (2013): Nurses awareness of patients' rights in a teaching hospital in community health centers. Faculty of medicin Ain Shams University, (112).
[31] Pitblado, JR (2005): "So, what do we mean by "rural," "remote" and "northern"?". The Canadian Journal of Nursing Research 37 (1): 163-8.

[32] Rich, K. (2013): Public health nursing ethics, nursing ethics; across the curriculum and into practice. (3th ed.). Burlinglon, MA: Jones \& Bartlett learning.

[33] Sinclair, J., (2015): New Zealand nursing students' experience of ethical issues in clinical practice, Master of Nursing, Eastern Institute of Technology, Taradal New Zealand.

[34] Smith, A., Bensink, M., Armfield, N., Stillman, J., \& Affery, L. (2015): elemedicine and rural health care applications. Journal of Postgraduate Medicine. 2005; 51: 286-293.

[35] Suasan, J., \& Cherry, B. (2014): Contemporary Nursing Issues, Trend, Management. ( $6^{\text {th }}$ ed.). Elsevier Mosby, USA.

[36] Thompson, J. E. (2007): professional ethics, In L. A. Ament. (Ed), professional issues in midwifery (PP. 277-300) SUDBURY. MA: Jones and Bartlett.

[37] Victoria Department of Education and Early Childhood Development, (2014): Maternal and Child health services; Victoria, ISBN 978-0-7594-0761-9 http://www.education. vic.gov.au / child hood / professional /health / pages /Mch policy.

[38] World Health Organization (WHO), (2014): Country Cooperation Strategy for WHO and Egypt, Printed by WHO Regional office for the Eastern Mediterranean, Cairo. Available at: www.emro.who.int/programmes/maternal-andchildhttp://en.wikipedia.org/wiki/Rural area.

[39] Yoost, B, \& Crawford, L., (2013): Fundamentals of nursing active learning for collaborative practice's, Elsevier/Mosby., USA, ISBN978-0-323-29. 